\title{
Cutaneous Melanoma pNX TNM Finding v6
}

National Cancer Institute

\section{Source}

National Cancer Institute. Cutaneous Melanoma pNX TNM Finding v6. NCI Thesaurus. Code C48854.

Cutaneous melanoma in which the regional lymph nodes cannot be assessed. (from AJCC 6th Ed.) 